\title{
How journalism experience translates to social entrepreneurship: An intention formation study of the Art Yard at Dadaocheng in Taiwan
}

\author{
Huei-Ching Liu ${ }^{1}$ (D) and Chaoyun Liang ${ }^{2}$
}

\begin{abstract}
Purpose: In this study, the story of the Art Yard at Dadaocheng, Taipei, Taiwan, was adopted as a case study. We thoroughly investigated the founder, a former television reporter, and her social entrepreneurial intention (SEI) to initiate a social enterprise. Methodology: By integrating the two classic models of entrepreneurship intention, entrepreneurial event theory and theory of planned behavior, we investigated the antecedents of SEI (i.e., empathy, entrepreneurial alertness, entrepreneurial selfefficacy, social responsibility, and social capital and support). Findings: The founder possessed capability of communication and coordination because of her professional journalism experience and successfully introduced her passionate empathy and profound sense of social responsibility into her entrepreneurial aspirations. Her entrepreneurial alertness and self-disciplined entrepreneurial self-efficacy originated from in-service education and inspiration through action. Social networks accumulated during her journalism career did not represent the primary source of support when establishing her social enterprise. In this research, two additional antecedents of SEI were identified: knowledge capital and work experience. Implications for theory and practice: Social entrepreneurial attitudes can be developed on the basis of passionate empathy and social entrepreneurial alertness is required to address the professional development needs in service programs. Social entrepreneurial selfefficacy in communication and marketing management is closely associated with the journalism profession, and the journalistic passion for social justice can motivate social responsibility activities. Careful selection, maintenance, and transformation of business partners for social support are essential. Originality and value: $A$ new

1 Huei-Ching Liu, Assistant Professor, Department of Communications Management, Shih Hsin University, Taipei, No. 1, Ln. 17, Sec. 1, Muzha Rd., Wenshan Dist., Taipei City 116, Taiwan; e-mail: audrey@mail.shu.edu.tw (ORCID: https://orcid. org/ 0000-0002-7423-0488).

2 Chaoyun Liang, Ph.D., Distinguished Professor, Department of Bio-Industry Communication and Development, National Taiwan University, Taipei, No. 1, Sec. 4, Roosevelt Road, Taipei, 10617, Taiwan; e-mail: cliang@ntu.edu.tw (ORCID: https:// orcid.org/0000-0001-6608-7717).
\end{abstract}

Received 27 November 2019; Revised 22 January 2020, 1 April 2020, 18 May 2020; Accepted 1 June 2020. This is an open access article under the CC BY license (https://creativecommons.org/licenses/by/4.0/legalcode). 
SEI theory was subsequently proposed for future research, and practical implications were addressed for social entrepreneurship.

Keywords: entrepreneurial intention, journalist, social entrepreneurship, the Art Yard

\section{INTRODUCTION}

Social entrepreneurship is thriving worldwide. From 1995 to 2005, the number of nonprofit organizations (NPOs) registered by the United States Internal Revenue Service increased by $53 \%$. Many NPOs have changed their business operations with a slowdown in the global economy to create financial autonomy (Pen \& Liang, 2019; Shapiro, 2012). The United Kingdom is often perceived as a pioneer of social entrepreneurship; the number of social enterprises established since 2005 has grown to over 13,000, three times more than ordinary small- and medium-sized enterprises. In the United Kingdom, there are approximately 70,000 social enterprises that contribute 2.4 billion pounds to the national economy and employ nearly one million people (Temple, 2017). Promoting social entrepreneurship is crucial for sustainable economic development in the Asia-Pacific region, particularly in highly urbanized areas such as those in Taiwan. However, few research studies have focused on this topic, and many questions remain unanswered (Liang, Ip, Wu, Law, Wang, Peng, \& Liu, 2018).

The Republic of China is the legitimate government of Taiwan, although the People's Republic of China continues to claim that Taiwan is under its governance. Even though Taiwan has enjoyed rapid economic growth and democratization, both industrialization and democratization have created obstacles for sustainable development. For example, the implementation of environmental practices is impeded by numerous stakeholders with greatly divergent interests. Consequently, attention towards social entrepreneurship is increasing (Liang et al., 2018; Wu, Wu, \& Wu, 2018). The Executive Yuan in Taiwan announced the 'Social Enterprise Action Plan' in 2014 to provide a clear definition of what constitutes social entrepreneurship. The objectives of Taiwanese social entrepreneurs include creating employment opportunities for disadvantaged groups, enhancing the self-sufficiency of organizations, and providing vocational training (Kuan \& Wang, 2016).

Social enterprises are organizations aiming to resolve social problems by the action of social entrepreneurs who work to establish links between social missions and entrepreneurial actions in organizations (Liu, Liang, Chang, Ip, \& Liang, 2020). The operation of a social enterprise must meet its social mission, which demands the pursuit of commercial profits (Carroll \& Shabana, 2010). Giving priority to social responsibility is almost identical to the professional 
conduct required of journalists. Under professional training in the workplace, journalists frequently make contact with socially disadvantaged and public interest groups. Fornews reporting, journalists must start from a point of truth and accuracy, independence, fairness and impartiality, humanity, and accountability (EJN, 2018). Smith (2012) indicated that many journalists who have changed their careers would most likely invest in NPOs. $84 \%$ of the participants in Smith's study believed that social entrepreneurship is increasingly important and would devote themselves to entrepreneurial goals to change the world.

Although journalism-based social enterprises, such as NeighborWebSJ, devoting themselves to social innovation and pursuing fairness and justice have increased in recent years, few studies regarding the engagement of journalists in social entrepreneurship have been conducted. This case study investigated the social entrepreneurial intention (SEI) of a renowned TV journalist through the story of the Art Yard at Dadaocheng, Taipei, Taiwan. The entrepreneurial goal of the Art Yard was to preserve the original appearance of traditional buildings and the local culture of 'Old Taipei' by attracting the young generation to engage in the community development movement. In this study, special attention was paid to the advantages and disadvantages of a journalism background when initiating a social enterprise in cultural and creative $(C \& C)$ industries. Classic theories of entrepreneurial intention were adopted: entrepreneurial event theory (EET) (Shaper \& Sokol, 1982) and theory of planned behavior (TPB) (Ajzen, 1991). This study validated and expanded upon these theories through a case study of the transition from journalism to social entrepreneurship.

The research questions in this study are as follows:

\section{RQ1: What antecedents influence journalists' intentions to become social entrepreneurs?}

RQ2: How do these antecedents affect the journalists' intentions?

This article is structured as a formal academic report: first related literature is reviewed, then the research methods, results, and discussion are presented. The article ends with conclusions and reflections.

\section{LITERATURE REVIEW}

\section{Journalism and social entrepreneurship}

News demands are immediate; therefore, mobility is paramount and a challenge in the lives of journalists. With the trend of digital convergence, 
many journalists choose to leave media organizations in response to an uncertain future. Many of them transform themselves into self-branded journalists (Cohen, 2015), focusing on innovative media experiments or promoting public services, and rebuilding public trust (Fancher, 2010). They operate as social entrepreneurs (Smith, 2012) who use commercial methods to combine social and financial goals, and achieve community ideals and innovation (Alegre, Kislenko, \& Berbegal-Mirabent, 2017). In particular, entrepreneurial journalists who left media organizations to start their own businesses mostly have 'changing the world' as their development goal. Without the boundaries set by media organizations, they often can emphasize the public interest and promote social values; this is trending towards the mainstream of news media in the next century (Liu, Chang, Liang, Ip, \& Liang, 2019; Smith, 2012).

Journalists and social entrepreneurs share many similar qualities. Both of them attach value to social responsibility (Carroll \& Shabana, 2010). Both of them are curious regarding the world and sensitive to problems in almost all aspects of society (McManus, 2015). Journalists and social entrepreneurs often have the opportunity to contact leaders from all walks of life and hear or witness innovative ideas and practices. They also often face budget pressures and continually changing network technology (McManus, 2015). Moreover, they both must be adaptable, highly creative (Berglez, 2011; Smith, Bell, \& Watts, 2014), and possess diverse social networks (Mehrotra \& Verma, 2015; Richards, 2013) to achieve their professional goals. Recent studies have found that journalists have strong self-efficacy and can creatively utilize their social capital to resolve complex social problems (Liu et al., 2019; Liu, Ip, \& Liang, 2018).

\section{Integration of EET and TPB}

The prerequisite for becoming an entrepreneur is intention (Fayolle, Gailly, \& Lassas, 2006); therefore, this study investigated antecedents and their influence on journalists' SEI. Entrepreneurial intention refers to the determination and preparation to create a new business or add value to an existing organization (Krueger, Reilly, \& Carsrud, 2000; Thompson, 2009). Entrepreneurial intention is a robust predictor of entrepreneurial behavior and guides entrepreneurship (Kolvereid \& Isaksen, 2006; Krueger, 2007). In the context of this study, SEI refers to the conviction and preparation of a journalist to create a new social enterprise or transform an existing organization into a social enterprise.

EET, proposed by Shapero and Sokol (1982), is a well-known theory of entrepreneurial intention, in which perceived desirability, propensity to act, 
and perceived feasibility are the three antecedents. Perceived desirability refers to the degree of attractiveness of an intended act to individuals. Propensity to act refers to the personal disposition to act on decisions in behavioral opportunities. Perceived feasibility refers to the degree of personal competence and resources necessary to accomplish the intended act. Another widely adopted model is TPB proposed by Ajzen (1991), which considers attitude towards the behavior, subjective norm, and perceived behavioral control as its critical antecedents. Attitude towards the behavior refers to the personal perception of the behavioral outcome. Subjective norm refers to personal perception regarding the expectations or pressure of valued reference individuals and motivation for complying with these referents. Perceived behavioral control refers to the personal perception of how well the behavior will be performed, encompassing the resource availability and self-efficacy required to perform the behavior.

Studies have confirmed both EET and TPB to be robust models for detecting entrepreneurial intention and suggested that they be integrated into a theoretical basis (Marina, Solesvik, Westhead, Kolvereid, \& Matlay, 2012; Mwatsika, 2015; Najafabadi, Zamanim, \& Mirdamadi, 2016). Davidsson (1991) argued that perceived desirability in EET and attitude towards behavior in TPB could be integrated because they both concerned the expectation of the behavioral outcome. Krueger (1993) suggested that the concepts of perceived feasibility in EET and perceived behavioral control in TPB were similar, both referring to self-efficacy and resource availability required to perform the behavior. Therefore, the predictors of entrepreneurial intention, after we integrated EET and TPB, consist of entrepreneurial attitude (i.e., perceived desirability), propensity to act, subjective norm, and perceived behavioral control (i.e., perceived feasibility). Perceived behavioral control can be further divided into two dimensions: self-efficacy (intrinsic control) and social capital (extrinsic control) (Ajzen, 2002).

\section{SEI research framework}

Taking characteristics of social entrepreneurship into account, Mair and Noboa (2006) proposed an SEI model based on TPB that has been adopted and tested by several studies in different countries (Forster \& Grichnik, 2013; Ip, Wu, Liu, \& Liang, 2017; Tukamushaba, Orobia, \& George, 2011). Considering the context of social entrepreneurship, Mair and Noboa (2006) proposed to substitute entrepreneurial attitude with empathy to reveal the established means of thinking or feeling towards others. Empathy has been lengthily studied in the context of helping behavior and identified as an innate predictor of SEl (Liu et al., 2020; London, 2010; Miller, Grimes, 
McMullen, \& Vogus, 2012). In addition, scholars have suggested corporate social responsibility (CSR) as an essential antecedent of SEI because CSR is closely associated with the contemporary business context and government regulations (Liang et al., 2018; Singh, Majumdar, \& Saini, 2017). Furthermore, the authors contended that entrepreneurial alertness should replace propensity to act because these two concepts concern behavioral tendency as it relates to an individual decision, but entrepreneurial alertness is much closer to entrepreneurship than is the propensity to act. Entrepreneurial alertness is an entrepreneur's ability to identify opportunities that are overlooked by others through scanning and searching, association and connection, and evaluation and judgment of business information (Liang, Liang, \& Liu, 2017; Tang, Kacmar, \& Busenitz, 2012).

In summary, five antecedents of SEI were reviewed based on the aforementioned literature in this study: empathy (to replace entrepreneurial attitude), entrepreneurial alertness (to replace propensity to act), entrepreneurial self-efficacy (to replace intrinsic behavioral control), social responsibility (to replace social norms), and social capital and support (to replace extrinsic behavioral control). Figure 1 illustrates the research framework of this study based on the aforementioned literature.

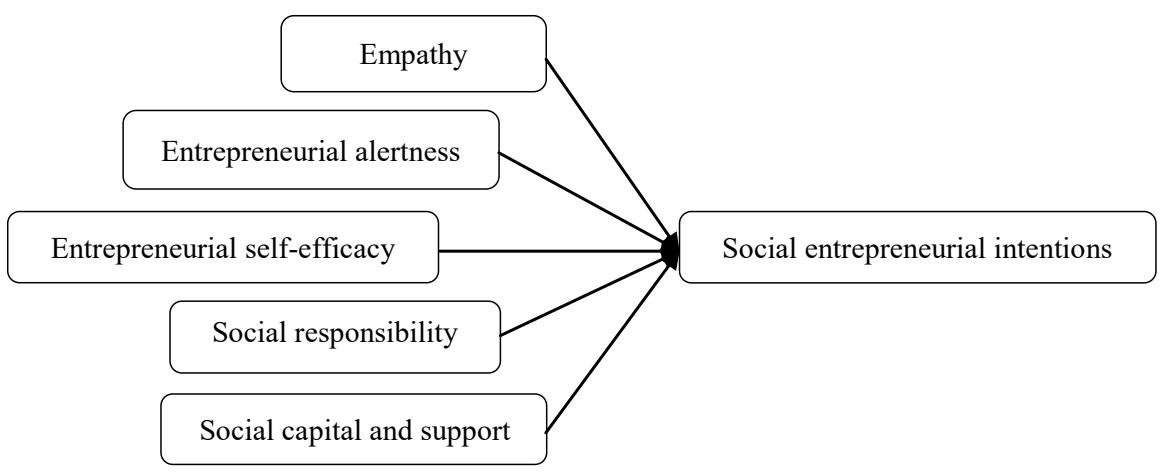

Figure 1. Research framework of SEI

\section{METHODS}

The case of the Art Yard at Dadaocheng, Taipei, Taiwan, was adopted as the study focus. We systematically studied the founder's SEl of initiating a social enterprise. The founder, a woman in her 40s, longed to become a journalist since her youth. Soon after graduating from a journalism program at a renowned university in Taiwan, she became a television reporter focusing on political news 
and was routinely rushed around the Presidential Office Building, Executive Yuan, and the Democratic Progressive Party Central Committee headquarters. During her first 5 years, she also served as an anchor and a talk show host. This experience and her outstanding performance led her to become the director of a political news center in her late 20s. However, during the $15^{\text {th }}$ year of her journalism career, she decided to quit TV news work and transformed herself into a social entrepreneur with the intent of preserving local Taipei culture. In addition to her skill in addressing obstacles, she has acted simultaneously as a facilitator, activity planner, and resource integrator.

We integrated two theories of entrepreneurial intention (i.e., EET and TPB) as the theoretical basis for this single case study. We entered the field to observe, record, and clarify the application and problems of theories to refine them. We first participated in the Tua-Tiu-Tiann International Festival of Arts series held by the founder at the end of 2017, which included parades, stalls, a carnival, and community forums. In addition to taking observation notes, we recorded a video of events to be used as supplementary data for final analysis. We also collected all relevant press releases, brochures, and video clips regarding the Art Yard, as well as news reports from television, newspapers, and social media throughout 2018. All of this first-hand information served as data for triangulation validation.

Based on the aforementioned information and literature, we conducted two rounds of semistructured in-depth interviews with the founder. Semistructured interviews often begin with informal and unstructured interviewing to allow researchers to develop an understanding of the topic of interest necessary for developing relevant and meaningful questions in a flexible and responsive manner (Cohen \& Crabtree, 2006). During the 100-150-min interviews, written consent forms were signed, and audio was recorded to transcribe them afterwards at the participant's workplace. The interview outline was developed to provide topic guides consisting of five prompts to facilitate the founder in elaborating on her views and experiences:

1) Empathy: Among numerous options, why did you eventually settle on the Art Yard as a C\&C business venture? What about it did you find attractive and meaningful? How did you empathize with the local people in the target community?

2) Entrepreneurial alertness: How did the knowledge diffusion from sales to hosting events become a highlight of the C\&C market? How do you identify business opportunities and create prospects for C\&C products and services? How do you expand your accumulated experience?

3) Social responsibility: How do you control the quality of C\&C products and services? What social returns do your products and activities emphasize? 
How do you utilize revenue? How do you invest the profits? What is the major contribution of the Art Yard to Taiwan's C\&C industry?

4) Entrepreneurial self-efficacy: How confident were you in the early days of the Art Yard? How did you self-regulate during that period? How much time did it take and what approaches did you use to convince your family and friends to support you?

5) Social capital and support: What opportunities and resources did you have before establishing the Art Yard? During the initiation period, how did you obtain financial support? How did you identify and utilize your business partners? How did you coordinate the division of labor among partners? How did you establish and how do you continue to expand the social network of the Art Yard?

After the field study, we collected all necessary data and proceeded with the following processing and analyses:

1) Information refinement: The collected data in audio and video form were converted into text. The in-depth interviews with the founder were transcribed, and the observation notes in the field were typed into Word format at the end of each event. Afterwards, the textual description was not modified, and the original appearance of the primary data was retained as the basis for analysis. To ensure data quality, each interview transcript was sent to the founder for confirmation and revision.

2) Content coding: After preliminary refinement and processing, the indepth interview transcripts were coded, indexed, and mapped according to the steps suggested by Graham-Rowe, Jessop, and Sparks (2014) to create a grounded theory model of analysis comprising open coding, focus coding, and axial coding. In the final stage of axial coding, we selected five recurring themes as SEI antecedents for the developed research framework (i.e., empathy, entrepreneurial alertness, entrepreneurial self-efficacy, social responsibility, and social capital and support). This coding process was conducted by two members of the research team, each performing coding tasks independently to avoid influencing each other. Cohen's kappa statistical test was used to measure intercoder reliability of agreement (i.e., dependability). The Cohen's kappa of this study was 0.82 (>0.70), indicating a significant correlation $(p<0.01)$ between the coders (Banerjee, Capozzoli, McSweeney, \& Sinha, 1999).

3) Triangulation validation: During the indexing and mapping process, various sources of research data were compiled and compared for triangulation validation and theme emergence. The synthesized data were examined to identify explanatory factors. We treated factors other than the five identified antecedents as emerging themes. We also compared the transcripts with the reviewed literature to determine if any topics required further investigation. This process was carefully 
conducted to ensure credibility and confirmability (Shenton, 2004). In addition, we used field pictures to illustrate the research context and field notes to describe the situations faced and the positions held by the founder to enhance the transferability for research outcome utilization in an evidence-based practical environment (Shenton, 2004).

\section{RESULTS AND DISCUSSION}

\section{Dadaocheng and the Art Yard}

In this case study, the founder of the Art Yard worked as a political correspondent, middle manager, and television reporter at a television station for 14 years. She resigned from the station not because of the deteriorating environment of mass media or digital convergence (Cohen, 2015) but because of the influence of her husband, who was participating in political movements, and the pursuit of viewership by television news stations. After leaving the media outlet, she founded a political party and participated in the 2016 lawmaker elections but was ultimately unsuccessful. To maintain its operation, her party had to transition from its original form; social enterprise presented a promising option. The founder recalled that her experience when conceiving the Art Yard was a whimsical one, similar to that of other artists who have a tendency to rely on inspiration. The selection of Dadaocheng as the start-up location was purely an impulsive decision.

'The headquarters of our party were close to the Legislative Yuan, so when we were starting up, we were often invited here (Dadaocheng) by friends ... My husband has an appreciation for old historic streets, and therefore, he visited Dadaocheng quite often.'

During Japanese rule, Dadaocheng was a crucial port in the greater Taipei area of Taiwan, where various products from traditional industries were traded (e.g., textiles, tea, Chinese medicine, and foodstuffs). Individuals from numerous walks of life, such as street vendors, craftsmen, artists, and businessmen, started businesses at Dadaocheng. During its peak period of development in 1920, Dadaocheng contained several of the most prosperous commercial areas in Taiwan (e.g., Yongleting, Taipingting, and Gangting), which featured department stores, trading companies, and dozens of cinemas. Under the influence of the trend of urban development of the east side of Taipei after 1920, Dadaocheng began to lose its glamour. In recent years, Taipei City has designated many of its districts as urban renewal areas, one of which is Datong District, where Dadaocheng is located. To protect 
historical and cultural heritage, the Taipei City government has implemented laws, regulations (e.g., property owners may apply for floor-area ratio transfer if their properties are designated as historic monuments), and incentive policies to encourage property owners to preserve historic property they own by repairing or reconstructing them to retain their original look.

\section{The five SEI antecedents}

\section{Entrepreneurial attitudes developed on the basis of passionate empathy}

Passionate about the historic streets, the founder and her business partners noticed several problems in Dadaocheng. The incentive policies for preserving historic landmarks through reconstruction promoted by the Taipei City government could only superficially maintain the appearance of old town houses instead of revitalize the former glory of Dadaocheng. In response to the decreasing number of visitors and challenges of operating shops at Dadaocheng, town house owners generally did not consider investing in reconstructing their buildings, because they would be unable to recover reconstruction costs. Thus, they tended to lack an interest in these incentive policies, allowing town houses at Dadaocheng to become dilapidated.

The founder not only understood deeply their situation but vicariously experienced their feelings. The founder transformed her empathy into C\&C organization, products, and activities. She exhibited exuberant passion in each stage of preparation for establishing the Art Yard. All entrepreneurial behavior originated from a sense of identification and fondness for a certain C\&C product. Empathy for a product drove her to learn more about it; she enjoyed the process of product development and transformed product research into a hobby. Generally, this passion agrees with the results of relevant SEl studies (Ip et al., 2017; Liang et al., 2018; Mair \& Noboa, 2006). The founder said the following of her passion:

'Without fully understanding a product, you will never make it great. We make a product because we really like it. I try to understand it because I identify with it, and I believe it can not only represent Dadaocheng but also "Old Taipei."”

'When I understand the product more, I grasp more accurately its essence. For each product we make, we have held long hours of discussion with the design director. This has become an enjoyable procedure in the process of starting up our business. For me, it has become a fun process. We did not care much about management and budget issues right at the beginning. We enjoy the process of creating a work.' 
Entrepreneurial alertness to fulfil the needs of professional product development

The displays of shops at Dadaocheng are generally old and outdated; shop owners prefer conservative business models and lack the motivation to transition their businesses. Therefore, they are unlikely to realize the value of creativity and innovation to the economic development of their respective industries. This leads to difficulties in maintaining businesses at Dadaocheng. Therefore, the founder established the Art Yard in 2011 as the first town house at Dadaocheng that serves as an entrepreneurial shop operating with a C\&C business model.

'The first town house, the Art Yard, was created after my husband and I stationed our business in the building with four groups of Taipei National University of the Arts (TNUA) students who specialized in cultural and creative development. We were at the stage of sharpening our tools, which means we were preparing for our start-up business, conducting product research and development, and finishing all of the preliminary procedures required for promoting our products in the market. After we had this town house, we combined all of the elements and entered the market ... From the final business outcomes, we saw that Dadaocheng does have sufficient cultural and entrepreneurial potential to be pursued and explored.'

Entrepreneurial alertness refers to the ability to discover new business opportunities in a market and utilize such opportunities (Kirzner, 1997). Applying this theory to our case study revealed that the founder emphasized the originality and individuality of C\&C products and distinguished them from other products through distinct market segmentation of customers, a finding consistent with results of prior research (Liang, 2019; Tang et al., 2012). When establishing her first brand, the founder even learned pottery-making techniques from a friend who was a ceramic artist. By learning through doing, the founder identified methods of cutting ceramic production costs and systemizing the manufacturing process.

If an artist creates a hundred artworks, all of them are different and unique. However, if you want to turn it into a brand and retain the same crafting method, then you must think of methods to build a systematic product development process ... You learn about the production process and then determine means of maintaining low costs as well as maintaining product quality during the production process without raising costs. We must devise various strategies, including packaging, product positioning, marketing, pricing, channeling, and promotion.' 
When employed as a reporter, the founder spent her free time and holidays investigating news events to keep herself abreast of the latest developments; however, she was never required to shoulder the burden of operating deficits as a business owner until she started her own business, which required her to sacrifice free time (which she sees as a necessary step), learn humility, and never lose focus.

'As an entrepreneur, you are no longer off on Saturdays, Sundays, or even holidays ... You raise questions and learn when encountering things that you don't know ... Life is work, and work is life. You may have your mind on work in any second of life. Always keep alert!'

Entrepreneurial self-efficacy in communication and marketing management

The founder claimed that in addition to product development, communication is the most crucial skill required for social entrepreneurship, which is a critical aspect of entrepreneurial self-efficacy (Drnovšek, Wincent, \& Cardon, 2010; McGee, Peterson, Mueller, \& Sequeira, 2009). Particularly, the founder attributed her communication skills to the professional training she received as a journalist:

'The ability to express yourself is critical, because you must communicate with companies and suppliers as well as train employees and negotiate with partners. Communication skills are required for so many things.'

'In that work environment, we had to utilize communication skills to reach certain goals ... Simply put, we had to become quick-witted and readily responsive after receiving professional training at work. Moreover, we acquired logical reasoning and integration skills through the journalistic training.'

During the interview, the founder exhibited rational and logical thinking. As if still a news reporter, she spoke fluently, eloquently, and unceasingly when facing the camera, but in a calm tone. When narrating her life's stories, she remained objective, as if covering a news story. When serving as the host of community forums, the founder does not introduce a speaker in an abstract and exhaustive manner; instead, she provides concrete information about the speaker's family background, type of business, and community agenda he or she intends to promote. Prior to a forum, the founder has indepth discussions and develops a rapport with speakers. She also encourages local residents to participate in meetings and even become speakers.

According to the founder, marketing management ability enhances her SEl. Here, marketing management skills were demonstrated when she 
organized a costume parade at the Tua-Tiu-Tiann International Festival of Arts. The parade, which took place on 14 October 2017, was a jointly organized event conceived and implemented by the founder and her business partners. The theme was '1920', the year at the height of Dadaocheng's development. Parade participants were requested to dress as celebrities from 1920 in blouses, overalls, and qipao, dresses with floral patterns. Despite heavy rainfall, more than 1,000 people attended the parade, which was broadcast live from multiple satellite news vehicles sent by television stations. On the same day, more than ten online news outlets covered the event with articles exceeding 300 words. The scale of the news coverage suggested that the parade gained sufficient media exposure. All the news articles covered the event by emphasizing its dedication to the history and culture of Dadaocheng in 1920, indicating that the promotional strategy achieved the original goal of cultural representation.

When describing her workload as a social entrepreneur, the founder remained at ease. She did not see the mix of work and life as a heavy burden. Instead, she regarded self-discipline as an essential element, consuring with recent studies (Liu et al., 2020; Pen \& Liang, 2019). Her ease and self-discipline originated from not only confidence cultivated through her professional experience and dedication to continuous learning but also from her fervent and firm entrepreneurial attitude. She invested her time in things in which she had an interest, lending additional support to the latest research (Ip, Liang, Wu, Law, \& Liu, 2018; Liu et al., 2020). By examining her work experience and continued learning, our case study elucidated the development of her self-efficacy, which showed similar patterns to those found by Wilson, Kickul, and Marlino (2007), and provided analytical results that are beneficial to establishing a research framework for investigating SEl. Describing her workload, she stated,

'An entrepreneur definitely has less free time than an office worker ... because starting up a business requires considerable self-discipline. No one pushes you but yourself. You must be highly self-disciplined.'

Social responsibility resulting from the motivation of social justice and concern

Since becoming a journalist, the founder learned concern for social justice. After leaving the media outlet for a social venture, she never abandoned her original intention to fulfill social responsibilities.

'I wanted to be a news reporter since I was little ... I developed a strong social purpose by devoting to the action of upholding social justice or exposing unfairness or injustice. Therefore, our enterprise is oriented toward a business 
for social purpose. [Our business] is expected to be both idealistic and realistic ... contribute to society with a social purpose, but also be commercially successful. This is our ultimate goal.'

The founder elaborated upon her vision for fulfilling social responsibilities with a firm look and tone of voice. She applied her vision to operating her business. She only discussed information pertaining to the content and purpose of the cultural event when meeting former coworkers or subordinates during the costume parade. When asked about detailed business information, such as shop rental expenses, she intentionally avoided exploiting her media background to promote her business. Even during the in-depth interview, she emphasized her wish to skip topics that may reveal business secrets.

'We all wish that the media covers more cultural and art information regarding Dadaocheng than business information that leads to commercial manipulation, because we are afraid that the rental prices in this area may be speculated upon.'

Although a social enterprise requires profit to sustain its operation, the founder did not adopt a market-oriented approach when deciding which industry she intended to promote at Dadaocheng. Instead, she focused on adapting local traditions to generate alternative and novel value from the history, culture, and community of Dadaocheng. This mindset showcases her pursuit of social justice as well as the similarities between her as a journalist and a social entrepreneur, both of whom value social responsibilities and are concerned with people of all social statuses (Carroll \& Shabana, 2010; Ip et al., 2018; Liang et al., 2018; McManus, 2015). When discussing this approach, she stated,

'Can we design a pattern that instantly reminds people of Taiwanese style? We think that Coworker A has a great starting point for product design because he has a background in arts; thus, many of the products they have designed well suit the image of Yongle Fabric Market, a place in Taipei that sells textiles and fabrics. If well-developed, his products may drive innovation and motivate other people to innovate local traditions.'

Careful selection, maintenance, and transformation of business partners for social support

Even a microenterprise requires business partners for proper business operation in the initial stage, during which business partners are essential to business development. The founder discussed her selection and coordination with business partners: 
'Many party members were friends that supported our vision. A great number of them were artists ... When initiating the political movement, I was studying at TNUA, during which I made acquaintances with numerous artists and young people at the university ... After our political reform ended, I had the idea of starting a business, which did not seem difficult at all since we had already started a political party by ourselves.'

'We have certain principles for selecting business partners. First, our partners must possess potential for social entrepreneurship, which means that they should have courage and determination. Second, being a partner is a fulltime job; thus, our partners must protect their reputation for the business they intend to develop ... In particular, we want them to have the ability to solve problems and be a leader. We sought business partners that did not intend to chase market trends and cater to the market ... For a start-up business, following others' paths means failure and complete loss of an entrepreneurial niche.'

Only if the partner candidate meets the aforementioned criteria would the founder further evaluate whether the person exhibits the creative capacity for the previously described market segmentation. The founder abandoned her tendency to take control as a middle manager by modifying her attitude towards collaborating with other businesses. When collaborating with partners from various industries, the founder inevitably had arguments with partners in the processes of communicating and coordinating in the initial stage; however, she formed strong trusting relationships and reached agreements through negotiation:

'Now, when supervising young business partners, I often give them the freedom to fail even when I know they will inevitably take a fall. I think that after one fall ... they might proceed down a road they never imagined ... as long as they manage to stand up again after the fall.'

'When operating a small business, we express our feelings and opinions in a straightforward manner. Everyone responds readily and follows directions immediately without administrative red tape. We develop teamwork quite rapidly. Sometimes you may overstep your authority to others. They may argue with you by stating that they have a clearer picture than you do, because these are their responsibilities as opposed to yours. Everyone has their own style of doing things, or they see things differently when making a certain decision ... This happens not just between my business partners and I; even my husband argues with me frequently, which is very common during the process of starting a business. With a solid cooperative relationship based on trust, we never hold grudges after a fight, because we do not take things personally.' 
All conflicts and disputes ended in reconciliation through communication. The founder has a solid relationship with her business partners but also a friendly relationship with local residents of Dadaocheng. She described this relationship as follows:

'Dadaocheng is like a small rural town in Taipei. When dining in a local restaurant, I am often treated to additional side dishes by the restaurant owner. They are more like a friend or family member than a business partner.'

This statement can be confirmed by her interaction with local business owners at the festival. They asked to take photos together and even offered her merchandise as gifts; this demonstrates a high level of trust and anticipation of cooperative opportunities. Owners proactively presented new products or business visions to the founder. Instead of merely exchanging pleasantries, they had conversations that suggested candid relationships. Unlike quantitative studies that have focused on the effects of social capital and support (Ip et al., 2017; Liang et al., 2018; Liu et al., 2018), the present study captured the dynamic process of establishing and maintaining social capital and support in social entrepreneurial activity and thus may provide insights into further research.

In addition to business partners, other social capital should be mentioned. Studies have confirmed that social capital is a beneficial resource that facilitates entrepreneurial activity among entrepreneurs and promotes an entrepreneurial spirit. Social capital is particularly beneficial for exchanging knowledge, identifying business opportunities, networking, establishing reputation, and improving performance (Partanen, Möller, Westerlund, Rajala, \& Rajala, 2008; Shaw, Lam, \& Carter, 2008). When she was a journalist, the founder met individuals from diverse backgrounds, allowing her to possess more social networks than the general public. She noted that she was advantaged in the initial stage of her social business, because she had easier access to media resources.

'We have an advantage in social networking. We have more networking resources than the general public does, whether it is cultural or social capital. If reporters cover our event, most of them are our friends ... We do have certain advantages in accessing media resources.'

The social networks that the founder obtained from her previous job as a political correspondent and middle manager did not provide substantial benefits for finding business partners or funding during the initial stage of establishing the Art Yard. She intentionally avoided using resources provided by 
media practitioners or agencies with which she had connections. She discussed the gradual establishment of the town homes and her attitude towards media:

'As a microenterprise, we did not require large funds. We now own a total of eight town houses, but actually, we established them one by one. The Art Yard is the first town house. We did not lease the entire building at the beginning ... At first, we only leased the second floor, then the third floor, and lastly the ground floor. Luckily, the ground floor was still available.'

'If we consider Dadaocheng as a site for business incubation ... time is required to create a business incubation hub for young entrepreneurs ... Particularly, we want to create an environment with no entry barriers ... but if this hub is established too quickly and is covered too frequently by media, then it will be turned into a target for speculation by local realestate owners. Once the rental prices increase, this will pose a substantial threat to entrepreneurs ... Actually, mass media is a double-edged sword; it brings benefits but also begets threats.'

The founder accumulated abundant social and media resources from her previous job as a reporter. However, these resources did not directly benefit her startup business during the initial stage. The partners she recruited were all people she met after leaving the field of media. She did not obtain funds from any of the social resources attained in her previous job. After realizing from practical experience that 'media is a double-edged sword' that creates both advantages and disadvantages for the C\&C industry and community cultivation, she avoided overusing the existing resources she had accumulated. Instead, she created social capital for her startup business by finding new resources. Her approach serves as impact of social capital on entrepreneurial intention (Liu et al., 2020; Partanen et al., 2008; Richards, 2013) and can inspire further discussions on how social capital creates public value and contributes to society.

\section{New SEI antecedents}

\section{Knowledge Capital}

In addition to the five SEl antecedents identified from the integration of EET and TPB, two themes emerged during the analysis: knowledge capital and work experience. During her journalism career, the founder spent free time studying news events to keep herself abreast of the latest developments. This custom originated from the knowledge she gained as a journalism student. The founder's competent communication and marketing management, as well as her social 
justice and concern, were cultivated during that period. Her knowledge capital of journalism greatly facilitated her SEI, a finding that is consistent with those of previous studies (Christopoulos \& Vogl, 2015; Kuckertz \& Wagner, 2010). Furthermore, in managing her start-up business, the founder demonstrated high levels of entrepreneurial alertness towards business opportunities and entrepreneurial self-efficacy in tasks similar to those she faced in her early career as a journalist. She often felt thankful for her journalism career, which had developed her capacity to adapt to social entrepreneurship:

'It is rather easy for a media practitioner to succeed in transitioning into a social branding or marketing role in a start-up company ... The knowledge and living customs cultivated as an undergraduate were quite helpful in developing my capacity to become a social entrepreneur.'

To further transform her products into a brand, she elevated her knowledge capital regarding business management through continued education at a university after establishing the Art Yard. She met many young artists who eventually became her business partners. Social networks have helped the founder to identify and work on new business opportunities with confidence. She spoke of her education:

I even took accounting classes at TNUA for the purpose of acquiring more product management knowledge ... Many young artists we met at TNUA supported our business, so we found many young partners there ... We collaborated for one or two years ... For instance, we have a friend who works at our machinery supplier, and one of our collaborating designers is a TNUA student who asked his friend to help design the interior of our shop. Their professional assistance helped me to recognize new opportunities in the market and to increase my confidence.'

As mentioned earlier, journalists and social entrepreneurs have similar attributes. Both groups attach value to social responsibility and often empathize and have contact with disadvantaged individuals from all walks of life (Carroll \& Shabana, 2010; McManus, 2015); hence, knowledge gained from the journalism program has enhanced her ability to empathize.

\section{Work experience}

Journalism work experience was the second emerging antecedent that greatly affected the founder's SEl; this finding is supported by prior research (Hockerts, 2017; Kuckertz \& Wagner, 2010; Yitshaki \& Kropp, 2015). To the founder, journalism experience most influenced her entrepreneurial self- 
efficacy, particularly that of communication and business management. A television news report lasts only 1.5 minutes on average, requiring a reporter to comprehensively narrate a news event and attract viewer attention within a short time; that is, a news reporter must be readily responsive. High work efficiency is an advantage for a journalist transitioning to another field (Liu et al., 2020). The founder applied this expertise to establishing her own brand.

'We make quick judgements ... I believe that our television news report training taught us to collect and interpret information, think, and make decisions immediately, which is positive for work efficiency.'

'What I am doing is brand establishment. [As former reporters], we know how to package a brand and ensure that the public receives our message positively or favorably. This is a skill that we learned from fields. An artist may not have such a skill ... If a journalist possesses specialized techniques, such as fashion design ... this may be helpful for developing new product and starting a business.'

Although she pursued high efficiency, the founder retained blind spots and consequently made erroneous judgements. The tendency of journalists to pursue work efficiency, the founder claims, can lead to stubborn opinions in the context of starting a business and increase the likelihood of misjudgment and lower the tolerance for failure.

'When we collect information too hastily, we tend to make self-righteous judgments that we think are accurate ... This is actually risky for a start-up business, because great opportunities for collaborative projects may be missed because of these subjective judgments... Therefore, I later adjusted my approach ... because I think that my previous approach may have led to blind spots ... and prevented me from making complete judgments, resulting in misjudgment for opportunity recognition.'

'[We] may become too opinionated or bossy. When I want every member to follow my directions, some of them cannot propose better ideas. In the field of media, we tend to be really careful at work, because we cannot afford to make any mistakes.'

'Taiwanese entrepreneurs generally cannot embrace failure when starting up a business. They treat failure seriously and associate it with complete and utter failure with their life or bankruptcy. Westerners and our friends from Silicon Valley regard entrepreneurial failure as a positive experience, because you only learn great lessons through failure.' 
Although the founder considered the possibility of misjudgment, overtly stubborn opinions, and low tolerance for failure as factors that impede journalists from creating a business, she also noted that journalists have substantial potential for handling administrative work through the integration of social supports in a start-up business.

'During the starting up process, I collected several knowledge management tools ... Any media practitioner could collect them immediately, because as I said, we are skilled at networking to solve problems and find solutions. Our resource integration and logical reasoning skills enable us to make quick decisions. We increase administrative efficiency considerably at the initial stage of starting up.'

The following is another example showing how professional journalism experience benefits SEl. During the festival, the founder visited each shop's booth and had a face-to-face discussion with shop owners regarding the products they intended to release in the near future. For instance, Shop A planned to release a series of retro matchboxes, for which the packaging was designed to depict the story of the owner's grandfather establishing a local film and television company. After listening to the backstory of the product and empathizing with the owner's inspiration, the founder immediately identified a candidate writer (social capital) from her mental database and formulated a concrete plan for cooperating with the writer (entrepreneurial alertness). Through listening and discussion, the founder accurately grasped the product philosophy of the owner of Shop A and formulated promotional strategies that were acceptable to the owner. She later assisted Shop A in planning and executing the launch event for the new products (entrepreneurial self-efficacy). Thus, she not only achieved the goal of innovating a traditional industry but also increased the willingness to repair and reconstruct Shop A's old town house (social responsibility).

Previous studies (Hockerts, 2017; Ip et al., 2018; Liu et al., 2020) have identified prior experience with social problems as a predictor of empathy, entrepreneurial self-efficacy, and social capital and support. This study's finding extends the research by suggesting that work experience can also serve as a predictor of entrepreneurial alertness and social responsibility.

\section{CONCLUSIONS AND REFLECTIONS}

The journalist in this study chose to abandon the media aura to create a social enterprise and realise the public value of self-identification. The process of 
social entrepreneurship is not like the one imagined by outsiders in which a journalist can transfer rich social networks and resources accumulated in the media world for use in a social venture to accelerate success. An entrepreneur must identify and build necessary resources conducive to the development of social entrepreneurship. The founder of the Art Yard exemplified this when she established her social enterprise at Dadaocheng.

Analyzing the case study reveals that the founder successfully introduced her passion and empathy and profound sense of social responsibility into her entrepreneurial aspirations. Accordingly, her keen entrepreneurial alertness and self-disciplined entrepreneurial self-efficacy came from inservice education and inspiration through action. As for the social networks accumulated during her journalism career, this social capital was not her primary source of support when establishing her social enterprise. We identified two additional SEI antecedents in the current study: knowledge capital and work experience. These two new antecedents, based on our interpretations, may also serve as the precursors of the five original SEI antecedents.

This study expanded the findings of prior research, but also has some limitations to note. First, the case study method typically incurs biases caused by researcher subjectivity or the time-consuming process. Even if the researcher tests repeatedly for credibility, transferability, dependability, and conformability, a case study remains limited by the chosen methodology. Second, the current study was also limited because we only included one social entrepreneur. A larger sample of social entrepreneurs would have been preferable to a single entrepreneur, even if that entrepreneur has been recognized as one of the most representative social entrepreneurs and as the first journalism-major social entrepreneur with related work experience in Taiwan.

This study has revealed six practical implications. First, social entrepreneurial attitudes can be developed on the basis of passionate empathy because journalists have a natural interest in the world and are sensitive to diverse systems and societies. Second, social entrepreneurial alertness is required to address the professional development needs in service programs, which include activity design, product sustainability, service delivery, and social ties. Third, social entrepreneurial self-efficacy in communication and marketing management is closely associated with the journalism profession. Fourth, the journalistic passion for social justice can motivate social responsibility activities in almost any aspect of society, particularly in terms of environmental and local cultural matters. Fifth, careful selection, maintenance, and transformation of business partners for social support are essential. Sixth, the knowledge capital and work experience gained through journalism benefit social entrepreneurship. 
This study has contributed to entrepreneurship theory by successfully integrating both EET and TPB, revising the variables, and validating the effectiveness of the integrated model. In the future, a multiple-case study should be conducted; that is, more journalism-major social entrepreneurs with professional experience should be studied to confirm the influence of knowledge capital and work experience on SEI. In addition, it could be quantitatively tested to determine how knowledge capital and work experience affect SEI through the mediation of empathy, entrepreneurial alertness, entrepreneurial self-efficacy, social responsibility, and social capital and support.

\section{References}

Ajzen, I. (1991). The theory of planned behaviour. Organizational Behaviorand Human Decision Processes, 50(6), 179-211.

Ajzen, I. (2002). Perceived behavioural control, self-efficacy, locus of control, and the theory of planned behaviour. Journal of Applied Social Psychology, 32(4), 665-683.

Alegre, I., Kislenko, S., \& Berbegal-Mirabent, J. (2017). Organized chaos: Mapping the definitions of social entrepreneurship. Journal of Social Entrepreneurship, 8(2), 248-264.

Banerjee, M., Capozzoli, M., McSweeney, L., \& Sinha, D. (1999). Beyond kappa: A review of interrater agreement measures. Canadian Journal of Statistics, 27(1), 3-23.

Berglez, P. (2011). Inside, outside, and beyond media logic: Journalistic creativity in climate reporting. Media, Culture \& Society, 33(3) 449-465.

Carroll, A. B., \& Shabana, K. M. (2010). The business case for corporate social responsibility: A review of concepts, research and practice. International journal of management reviews, 12(1), 85-105.

Christopoulos, D., \& Vogl, S. (2015). The motivation of social entrepreneurs: The roles, agendas and relations of altruistic economic actors. Journal of Social Entrepreneurship, 6(1), 1-30.

Cohen, N. S. (2015). Entrepreneurial journalism and the precarious state of media work. South Atlantic Quarterly, 114(3), 513-533.

Cohen, D., \& Crabtree, B. (2006). Qualitative research guidelines project. Retrieved May 1, 2014, from http://www.qualres.org/HomeSemi-3629.html

Davidsson, P. (1991). Continued entrepreneurship: Ability, need, and opportunity as determinants of small firm growth. Journal of Business Venturing, 6(6), 405-429.

Drnovš̀ek, M., Wincent, J., \& Cardon, M. S. (2010). Entrepreneurial self-efficacyand business start-up: Developing a multi-dimensional definition. International Journal of Entrepreneurial Behavior\& Research, 16(4), 329-348. 
EJN (2018). The 5 principles of ethical journalism. Ethical Journalism Network. Retrieved from: https://ethicaljournalismnetwork.org/who-we-are/5principles-of-journalism.

Fancher, M. R. (2010). Of the press: Models for transforming American journalism. A report of the 2009 Aspen Institute Forum on Communications and Society. Washington, D.C.

Fayolle, A., Gailly, B., \& Lassas, N. (2006). Assessing the impact of entrepreneurship education programmes: A new methodology. Journal of European Industrial Training, 30(8/9), 701-720.

Forster, F., \& Grichnik, D. (2013). Social entrepreneurial intention formation of corporate volunteers. Journal of Social Entrepreneurship, 4(2), 153-181.

Graham-Rowe, E., Jessop, D. C., \& Sparks, P. (2014). Identifying motivations and barriers to minimising household food waste. Resources, Conservation and Recycling, 84, 15-23.

Hockerts, K. (2017). Determinants of social entrepreneurial intentions. Entrepreneurship Theory and Practice, 41(1), 105-130. doi: 10.1111/etap.12171.

Ip, C. Y., Liang, C., Wu, S.-C., Law, K. M. Y., \& Liu, H.-C. (2018). Enhancing social entrepreneurial intentions through entrepreneurial creativity: A comparative study between Taiwan and Hong Kong. Creativity Research Journal, 30(2), 132-142. doi: 10.1080/10400419.2018.1446744.

Ip, C. Y., Wu, S.-C., Liu, H.-C., \& Liang, C. (2017). Revisiting the antecedents of social entrepreneurial intentions in Hong Kong. International Journal of Educational Psychology, 6(3), 301-323.

Kirzner, I. M. (1997). Entrepreneurial discovery and the competitive market process: An Austrian approach. Journal of Economic Literature, 35(1), 60-85.

Kolvereid, L., \& Isaksen, E. (2006). New business start-up and subsequent entry into self-employment. Journal of Business Venturing, 21(6), 866-885.

Krueger, N. (1993). Impact of prior entrepreneurial exposure on perceptions of new venture feasibility and desirability. Journal of Entrepreneurship Theory and Practice, 18, 91-105.

Krueger, N. F. (2007). What lies beneath? The experiential essence of entrepreneurial thinking. Entrepreneurship Theory and Practice. 31(1), 123-138.

Krueger, N. F., Reilly, M. D., \& Carsrud, A. L. (2000). Competing models of entrepreneurial intentions. Journal of Business Venturing, 15(5), 411-432.

Kuan, Y. Y. \& Wang, S. T. (2016). The Governance and Social Impact of Taiwan's Social Enterprises (2nd ed.). Taipei: Chu-Liu Book.

Kuckertz, A., \& Wagner, M. (2010). The influence of sustainability orientation on entrepreneurial intentions: Investigating the role of business experience. Journal of Business Venturing, 25(5), 524-539. doi:

Liang, C. (2019). How entrepreneur personality affects agrirural entrepreneurial alertness. Journal of Entrepreneurship, Management and Innovation, 15(1), 143-165. doi: 10.7341/20191516.

Liang, C., Ip, C. Y., Wu, S.-C., Law, K. M. Y., Wang, J.-H., Peng, L.-P., \& Liu, H.-C. (2018). Personality traits, social capital, and entrepreneurial creativity: Comparing green socioentrepreneurial intentions across Taiwan 
and Hong Kong. Studies in Higher Education, 44(6), 1086-1105. doi: 10.1080/03075079.2017.1418310.

Liang, C., Liang, C.-T., \& Liu, Y.-C. (2017). Leveraging entrepreneurial alertness by optimising the imaginative capacity of agrirural entrepreneurs. Business Creativity \& the Creative Economy, 3, 54-64. doi: 10.18536/ bcce.2017.10.3.1.05.

Liu, H.-C., Chang, C.-C., Liang, C.-T., Ip, C. Y., \& Liang, C. (2019). Kindling social entrepreneurial journalism. Journalism Practice, 13(7), 873-885. doi: 10.1080/17512786.2018.1564884.

Liu, H.-C., Ip, C. Y., \& Liang, C. (2018). A new runway for journalists: On the intentions of journalists to start social enterprises. Journal of Entrepreneurship, Management and Innovation, 14(2), 83-100.

Liu, H.-C., Liang, C., Chang, C.-C., Ip, C. Y., \& Liang, C.-T. (2020). Optimising personality traits and entrepreneurial creativity to boost the precursors of social entrepreneurial intentions: Five studies in Taiwan. Journal of Social Service Research. doi: 10.1080/01488376.2019.1708840.

London, M. (2010). Understanding social advocacy: An integrative model of motivation, strategy, and persistence in support of corporate social responsibility and social entrepreneurship. Journal of Management Development, 29(3), 224-245.

Mair, J., \& Noboa, E. (2006). Social entrepreneurship: How intentions to create a social venture are formed. In J. Mair, J. Robinson, \& K.N. Hockerts (Eds.), Social Entrepreneurship (pp. 121-135). Basingstoke, U.K.: Palgrave MacMillan.

Marina, Z., Solesvik, M. Z., Westhead, P., Kolvereid, L., \& Matlay, H. (2012). Student intentions to become self-employed: The Ukrainian context. Journal of Small Business and Enterprise Development, 19(3), 441-460.

McGee, J. E., Peterson, M., Mueller, S. L., \& Sequeira, J. M. (2009). Entrepreneurial self-efficacy: Refining the measure. Entrepreneurship Theory and Practice, 33(4), 965-988.

McManus, K. (April 30, 2015). Why journalists make great entrepreneurs. Retrieved 20 January 2018 from http://mediashift.org/2015/04/whyjournalists-make-great-entrepreneurs/

Mehrotra, S., \& Verma, S. (2015). An assessment approach for enhancing the organizational performance of social enterprises in India. Journal of Entrepreneurship in Emerging Economies, 7(1), 35-54.

Miller, T. L., Grimes, M. G., McMullen, J. S., \& Vogus, T. J. (2012). Venturing for others with heart and head: How compassion encourages social entrepreneurship. Academy of Management Review, 37(4), 616-640.

Mwatsika, C. (2015). Entrepreneurship development and entrepreneurial orientation in rural areas in Malawi. African Journal of Business Management, 9(9), 425-436.

Najafabadi, M. O., Zamani, M., \& Mirdamadi, M. (2016). Designing a model for entrepreneurial intentions of agriculture students. Journal of Education for Business, 91(6), 338-346. 
Partanen, J., Möller, K., Westerlund, M., Rajala, R., \& Rajala, A. (2008). Social capital in the growth of science-and-technology-based SMEs. Industrial Marketing Management, 37(5), 513-522.

Pen, X.-E., \& Liang, C. (2019). Before nonprofit organisations become social enterprises. VOLUNTAS International Journal of Voluntary and Nonprofit Organizations, 30(3), 460-474. doi: 10.1007/s11266-018-00071-7

Richards, I. (2013). Beyond city limits: Regional journalism and social capital. Journalism, 14(5), 627-642.

Shapero, A., \& Sokol, L. (1982). Social dimensions of entrepreneurship. In C. A. Kent, D. L. Sexton, \& K. H. Vesper (Eds.), Encyclopedia of Entrepreneurship (pp.72-90). Englewood Cliffs, NJ: Prentice Hall.

Shapiro, R. A. (2012). The real problem solvers: Social entrepreneurs in America. Stanford University Press. http://www.sup.org/books/title/?id=20715

Shaw, E., Lam, W., \& Carter, S. (2008). The role of entrepreneurial capital in building service reputation. Service Industries Journal, 28(7), 899-917.

Shenton, A. K. (2004). Strategies for ensuring trustworthiness in qualitative research projects. Education for Information, 22(1), 63-75.

Singh, A., Majumdar, S., \& Saini, G. K. (2017). Corporate social responsibility and social entrepreneurship: An Indian context. Journal of Entrepreneurship and Innovation in Emerging Economies, 3(1), 71-76.

Smith, J. A. (2012). Journalism is becoming a form of social entrepreneurship. Stanford Social Innovation Review. 10(1), 23-25.

Smith, R., Bell, R., \& Watts, H. (2014). Personality trait differences between traditional and social entrepreneurs. Social Enterprise Journal, 10(3), 200-221.

Tang, J., Kacmar, K. M. M., \& Busenitz, L. (2012). Entrepreneurial alertness in the pursuit of new opportunities. Journal of Business Venturing, 27(1), 77-94.

Temple, N. (2017). The future of business: State of social enterprise survey 2017. Retrieved 10 January 2018 from: https://www.socialenterprise. org.uk/Handlers/Download.ashx?IDMF=a1051b2c-21a4-461a-896caca6701cc441

Thompson, E. R. (2009). Individual entrepreneurial intent: Construct clarification and development of an internationally reliable metric. Entrepreneurship Theory and Practice, 33(3), 669-694.

Tukamushaba, E. K., Orobia, L., \& George, B. P. (2011). Development of a conceptual model to understand international social entrepreneurship and its application in the Ugandan context. Journal of International Entrepreneurship, 9(4), 282-298.

Wilson, F., Kickul, J., \& Marlino, D. (2007). Gender, entrepreneurial self-efficacy, and entrepreneurial career intentions: Implications for entrepreneurship education. Entrepreneurship Theory and Practice, 31(3), 387-406.

Wu, Y. C., Wu, Y. J., \& Wu, S. M., (2018). Development and challenges of social enterprises in Taiwan: From the perspective of community development. Sustainability, 10(6), 1-17. 
Yitshaki, R., \& Kropp, F. (2015). Motivations and opportunity recognition of social entrepreneurs. Journal of Small Business Management, 54(2), 546-565. doi: 10.1111/jsbm.12157

Abstrakt
Cel: W tym badaniu jako studium przypadku przyjęto historię Art Yard w Dadaocheng
w Tajpej na Tajwanie. Dokładnie zbadaliśmy założycielkę, była reporterkę telewizyj-
nq i jej zamiar przedsiębiorczości społecznej (SEl), aby zainicjować przedsiębiorstwo
społeczne. Metodyka: integrujqc dwa klasyczne modele intencji przedsiębiorczości,
teorię zdarzeń zwiqzzanych z przedsiębiorczościq i teorię planowanego zachowania,
zbadaliśmy poprzedniki SEl (tj. empatię, czujność przedsiębiorczq, przedsiębiorczą
własnq skuteczność, odpowiedzialność społecznq oraz kapitał i wsparcie społecz-
ne). Wyniki: Założycielka posiadała zdolność komunikacji i koordynacji dzięki swo-
jemu doświadczeniu w dziennikarstwie zawodowym i z powodzeniem wprowadziła
w swoje aspiracje przedsiębiorcze pełnq pasji empatię i głębokie poczucie odpowie-
dzialności społecznej. Jej przedsiębiorcza czujność i samodyscyplina przedsiębiorczej
własnej skuteczności wywodzq się z doskonalenia zawodowego i inspiracji poprzez
działanie. Sieci społecznościowe nagromadzone podczas jej kariery dziennikarskiej
nie stanowiły podstawowego źródła wsparcia przy zakładaniu jej przedsiębiorstwa
społecznego. W tym badaniu zidentyfikowano dwa dodatkowe poprzedniki SEl: kapi-
tał wiedzy i doświadczenie zawodowe. Implikacje dla teorii i praktyki: Postawy zwiq-
zane z przedsiębiorczościq społecznq można rozwijać w oparciu o empatię, a czujność
przedsiębiorczości społecznej jest wymagana, aby zaspokoić potrzeby rozwoju zawo-
dowego w programach usług. Poczucie własnej skuteczności społecznej przedsiębior-
czości w zarzqdzaniu komunikacjq i marketingiem jest ściśle zwiqzane z zawodem
dziennikarza, a pasja dziennikarska do sprawiedliwości społecznej może motywować
do działań z zakresu odpowiedzialności społecznej. Niezbędna jest staranna selek-
cja, utrzymanie i transformacja partnerów biznesowych do wsparcia społecznego.
Oryginalnosć i wartosc: Zaproponowano nowq teorię SEl ukierunkowanq na przysze Oryginalność i wartość: Zaproponowano nowq teorię SEI ukierunkowanq na przyszłe badania i zajęto się implikacjami praktycznymi dla społecznej przedsiębiorczości.

Słowa kluczowe: intencje przedsiębiorcze, dziennikarz, przedsiębiorczość społeczna, dziedziniec sztuki

\section{Biographical notes}

Huei-Ching Liu is an Assistant Professor at the Department of Communications Management, Shih Hsin University, Taipei, Taiwan. She was a Senior Reporter in Liann Yee Production Co., Ltd., TVBS TV Network. Huei-Ching is currently a part-time doctoral student in the Department of Bio-Industry Communication and Development at the National Taiwan University. Her research interests focus on: media convergence, communication education, multimedia communication, and entrepreneurship. Miss Liu can be reached via HYPERLINK "mailto:audrey@mail.shu.edu.tw" audrey@mail.shu.edu.tw or audreyliou@gmail.com. 
Chaoyun Liang is a Distinguished Professor in the Department of Bio-Industry Communication and Development, National Taiwan University, Taipei, Taiwan. He gained his Ph.D. degree in the Instructional Systems Technology program at Indiana University, USA. His research interests focus on: imagination \& creativity, entrepreneurship \& social enterprise, and agrirural communication \& marketing. Professor Liang can be reached via cliang@ntu.edu.tw.

\section{Conflicts of interest}

The authors declare no conflict of interest.

\section{Citation (APA Style)}

Liu, H-Ch., \& Liang, Ch. (2021). How journalism experience translates to social entrepreneurship: An intention formation study of the Art Yard at Dadaocheng in Taiwan. Journal of Entrepreneurship, Management and Innovation, 17(1), 175-201. https://doi.org/10.7341/20211716 